\title{
sensors
}

ISSN 1424-8220

(C) 2007 by MDPI

www.mdpi.org/sensors

Full Research Paper

\section{Shapes of Differential Pulse Voltammograms and Level of Metallothionein at Different Animal Species}

\author{
Vojtech Adam ${ }^{1,2}$, Miroslava Beklova ${ }^{3}$, Jiri Pikula ${ }^{3}$, Jaromir Hubalek ${ }^{4}$, Libuse Trnkova ${ }^{4}$ and \\ Rene Kizek $^{1, *}$
}

1 Department of Chemistry and Biochemistry, Mendel University of Agriculture and Forestry, Zemedelska 1, CZ-613 00 Brno, Czech Republic

2 Department of Animal Nutrition and Forage Production, Faculty of Agronomy, Mendel University of Agriculture and Forestry, Zemedelska 1, CZ-613 00 Brno, Czech Republic

3 Department of Veterinary Ecology and Environmental Protection, Faculty of Veterinary Hygiene and Ecology, University of Veterinary and Pharmaceutical Sciences, Palackeho 1-3, CZ-612 42 Brno, Czech Republic

4 Department of Microelectronics, Faculty of Electrical Engineering and Communication, Brno University of Technology, Udolni 53, CZ-602 00 Brno, Czech Republic

5 Department of Chemistry, Faculty of Science, Masaryk University, Kotlarska 37, CZ-611 37 Brno, Czech Republic

* Author to whom correspondence should be addressed. E-mail:kizek@sci.muni.cz

Received: 1 October 2007 / Accepted: 17 October 2007 / Published: 19 October 2007

\begin{abstract}
Metallothioneins play a key role in maintaining homeostasis of essential metals and in protecting of cells against metal toxicity as well as oxidative damaging. Excepting humans, blood levels of metallothionein have not yet been reported from any animal species. Blood plasma samples of 9 animal species were analysed by the adsorptive transfer stripping technique to obtain species specific voltammograms. Quite distinct records were obtained from the Takin (Budorcas taxicolor), while other interesting records were observed in samples from the European Bison (Bison bonasus bonasus) and the Red-eared Slider (Trachemys scripta elegans). To quantify metallothionein the catalytic peak Cat2 was used, well developed in the Domestic Fowl (Gallus gallus f. domestica) and showing a very low signal in the Red Deer (Cervus elaphus). The highest levels of metallothionein reaching over $20 \mu \mathrm{M}$ were found in the Domestic Fowl. High levels of MT were also found in the Bearded Dragon (Pogona vitticeps) and the Grey Wolf (Canis lupus lupus). The lowest values of about 1-3 $\mu \mathrm{M}$ were determined in the Red-eared Slider, Takin and Red Deer.
\end{abstract}


Employing a simple electrochemical detection it was possible to examine variation in blood metallothionein in different species of vertebrates.

Keywords: Electrochemical detection; Catalytic signal; Brdicka reaction; Heavy metals; Red-eared Slider; Bearded Dragon; Domestic Fowl; Grey Wolf; Bactrian Camel; Reindeer; Takin; European Bison; Red Deer

\section{Introduction}

Regular cellular functions depend on the stability and minimal changes of the inner environment. Therefore it is not surprising that there are numerous regulatory mechanisms maintaining the inner environment in higher animals. The most extensively studied homeostatic mechanism is probably the buffering ability of body fluids maintaining optimum concentration of acids and alkalis (i.e. stability of $\mathrm{pH})$. All these homeostatic mechanisms are strictly controlled and many of them employ the negative feedback. It may be supposed that levels of heavy metal ions are also strictly controlled in all living organisms [1,2]. Free ions can cause many serious problems including oxidative stress or permanent signalling within the cell [3]. The bond between metals and albumin, though it is thought to be nonspecific, is important for the maintenance of homeostasis of metal ions. Specific proteins binding metal ions such as iron (ferritin) or copper (ceruloplasmin) have also been described.

One intracellular heavy metal binding protein, metallothionein (MT), was discovered in vertebrates in 1957 [4]. Its molecular weight ranges from 6 to $7 \mathrm{kDa}$ in all mammalian species and it may be characterised by a unique content of metal ions as well as sulphur [5]. It has a high affinity for various metal ions which may represent up to $20 \%$ of the metallothionein weight. Phylogenetic relations of various MT families were obtained by protein and gene sequencing. Based on the results obtained phylogenetically related families and subfamilies of evolutionary similar complexes of MT families in vertebrates can be distinguished (Figure 1). Primarily metallothioneins were divided into three classes. Class I includes MTs found in various mammalian species. Class II comprises all other protein MTs not belonging into class I. Class III contains metalloisopolypeptids with a gamma-glutamyl-cysteine unit. Sequentional similarity, however, may not be sufficient for the classification of MTs. Therefore, a definition of MT clans has been proposed. Clans unite MTs according to other characteristics such as their general structure, thermodynamics and metals-binding groups.

Metallothioneins are present throughout the animal kingdom and have also been found in higher plants, eukaryotic micro-organisms and many prokaryotes [5-7]. In animals they occur in tissues such as liver, kidney, pancreas and intestines, in particular [8-11]. There are considerable differences in the content of MT related to species, tissues, age, nutrition and other not well known factors [12-17]. Moreover, heavy metal ions in the environment play an important role. Their effects, however, are not fully understood [18-21]. There are probably constant levels of metallothionein in a non-stressed cell. Interestingly, metallothionein may accumulate within lysosomes and has also been found in the cellular nucleus [22-25]. Although metallothionein has been identified in a broad range of species, to our knowledge there has been published only one paper comparing systematic differences in various 
mammals including humans concerning species variation in hepatic metallothionein [26]. In the aforementioned study, however, tissue samples for metallothionein analysis were obtained from dead necropsied specimens. As blood levels of metallothionein might be of clinical importance, the objective of this study was to determine blood plasma levels of metallothionein of several species of vertebrates using electrochemical detection (adsorptive transfer stripping technique with differential pulse voltammetry Brdicka reaction - AdTS DPV Brdicka reaction), but the samples were collected from live specimens prior to analysis. The species studied include Red-eared Slider, Bearded Dragon, Domestic Fowl, Grey Wolf, Bactrian Camel, Reindeer, Takin, European Bison, and Red Deer.

\section{Phylogenetic tree of vertebrate metallothionein}

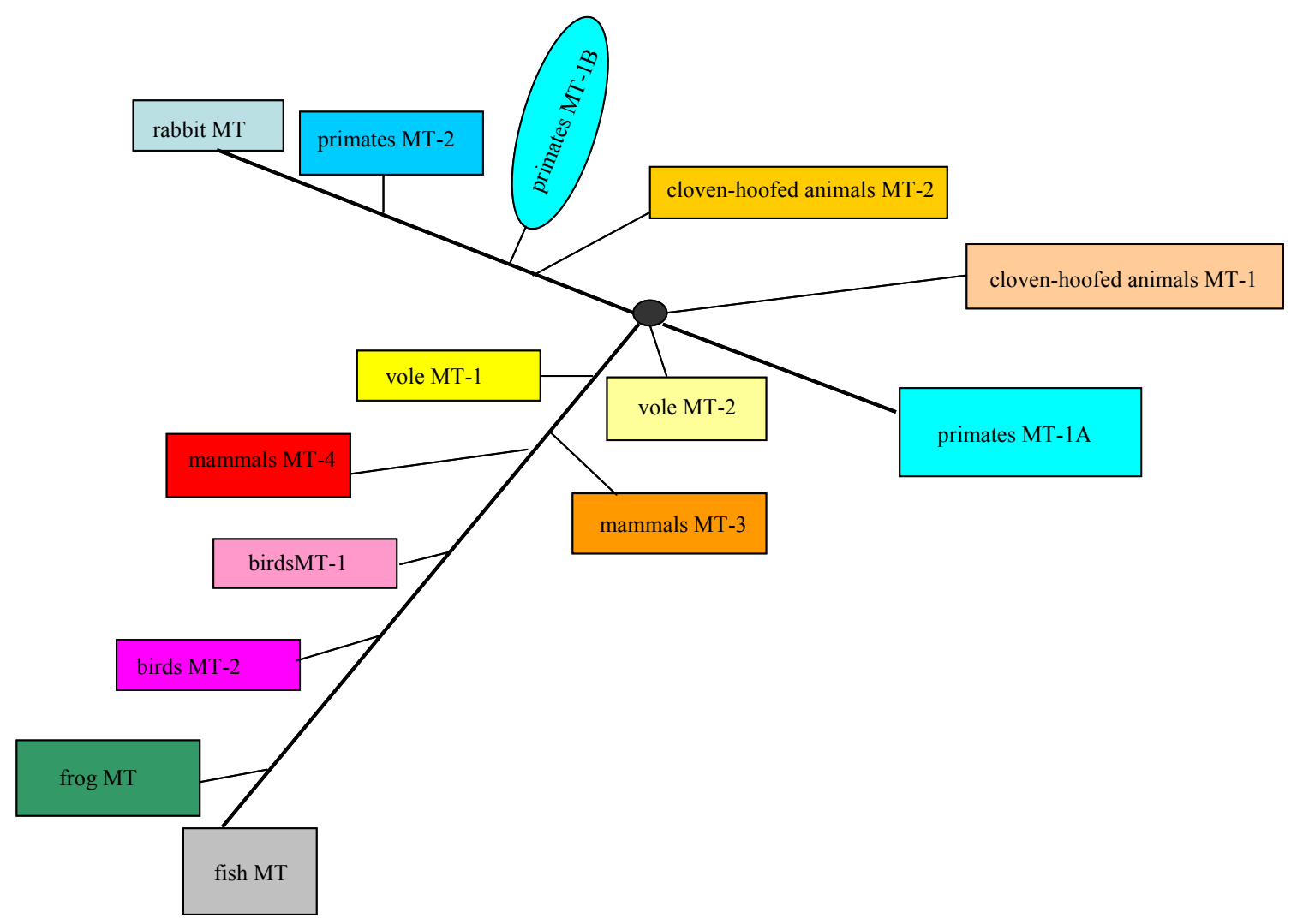

Figure 1. Phylogenetic tree of metallothioneins in vertebrates. Based on the data from www.expasy.ch.

\section{Experimental Section}

\subsection{Chemicals}

Rabbit liver MT (MW 7143), containing $5.9 \% \mathrm{Cd}$ and $0.5 \% \mathrm{Zn}$, was purchased from Sigma Aldrich (St. Louis, USA). Tris(2-carboxyethyl)phosphine (TCEP) was produced by Molecular Probes (Evgen, Oregon, USA). All other chemicals used were purchased from Sigma Aldrich unless noted otherwise. The stock standard solutions of MT at $10 \mu \mathrm{g} / \mathrm{ml}$ with $1 \mathrm{mM}$ TCEP [27-29] were prepared with ACS water (Sigma-Aldrich, USA) and stored in the dark at $-20{ }^{\circ} \mathrm{C}$. Working standard solutions were prepared daily by dilution of the stock solutions. 


\subsection{Electrochemical measurements}

Electrochemical measurements were performed with AUTOLAB Analyser (EcoChemie, Netherlands) connected to VA-Stand 663 (Metrohm, Switzerland), using a standard cell with three electrodes. A hanging mercury drop electrode (HMDE) with a drop area of $0.4 \mathrm{~mm}^{2}$ was used as working electrode. $\mathrm{An} \mathrm{Ag} / \mathrm{AgCl} / 3 \mathrm{M} \mathrm{KCl}$ served as reference electrode and glassy carbon electrode as auxiliary electrode. For smoothing and baseline correction the software GPES 4.4 supplied by EcoChemie was employed.

\subsubsection{Adsorptive transfer stripping technique}

Principle of the AdTS (Figure 2) is based on the strong adsorbing of the studied analyte on the electrode surface at an open electrode circuit. The excess of analyte is washed from the surface of the working electrode in the buffer. The adsorbed analyte is finally detected in the presence of supporting electrolyte [27,30-39].

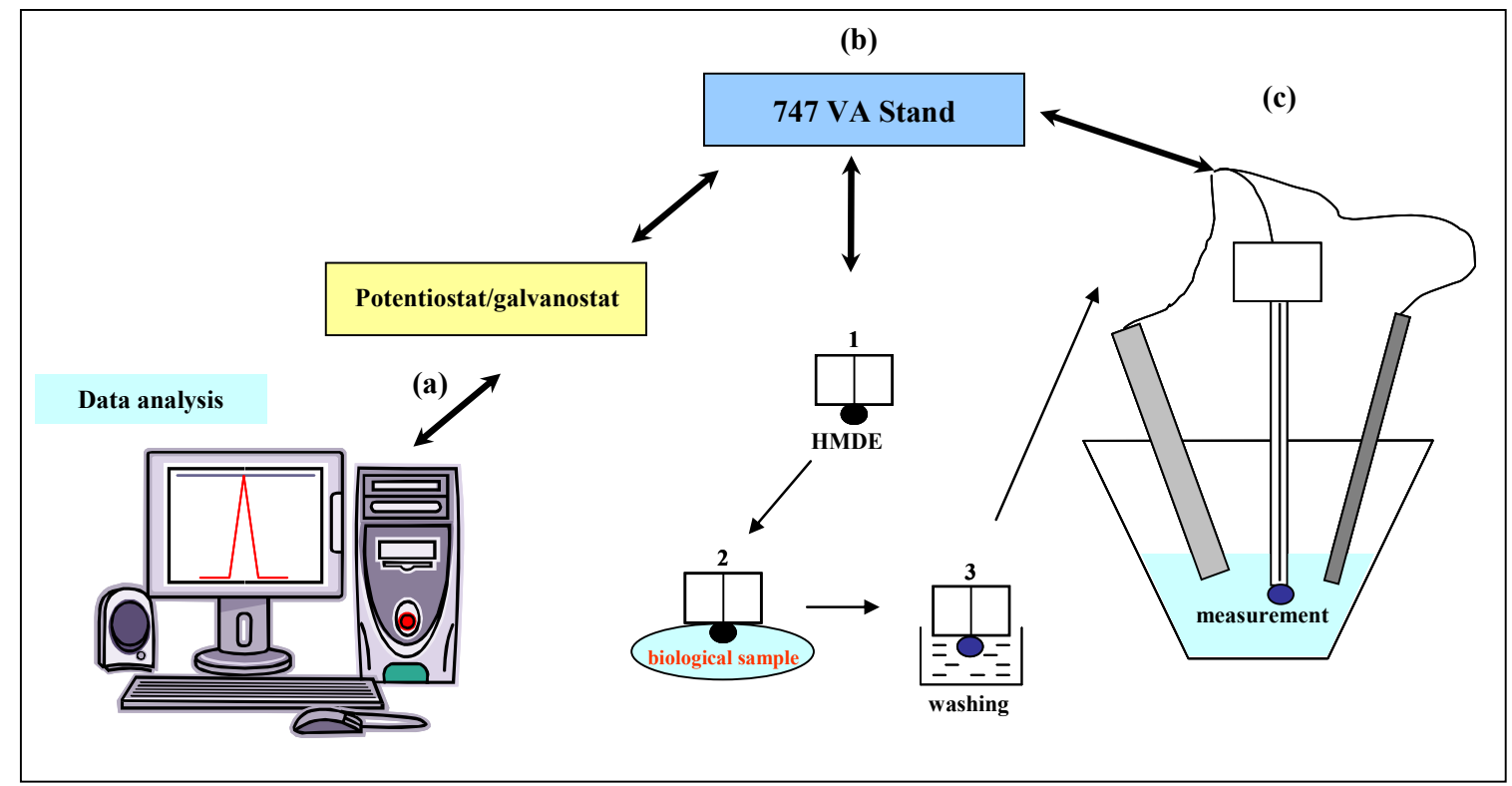

Figure 2. A scheme showing the electrochemical analysis using the adsorptive transfer. (a) Control unit - a computer directly connected to the potentiostat/galvanostat, (b) a system of electrodes containing reference, auxiliary and working electrodes. Working electrode-HMDE is renewed (1), then inserted into the sample solution where accumulation on its surface takes place (2); modified electrode is washed (3). (c) Subsequently, electrochemical detection takes place in the supporting electrolyte; the curve obtained is then analysed using the computer.

\subsubsection{AdTS DPV Brdicka reaction of MT}

The Brdicka supporting electrolyte containing $1 \mathrm{mM} \mathrm{Co}\left(\mathrm{NH}_{3}\right)_{6} \mathrm{Cl}_{3}$ and $1 \mathrm{M}$ ammonia buffer $\left(\mathrm{NH}_{3}\right.$ (aq) $\left.+\mathrm{NH}_{4} \mathrm{Cl}, \mathrm{pH}=9.6\right)$ was used; surface-active agent was not added. AdTS DPV Brdicka reaction parameters were as follows: an initial potential of $-0.35 \mathrm{~V}$, an end potential $-1.8 \mathrm{~V}$, a modulation time $0.057 \mathrm{~s}$, a time interval $0.2 \mathrm{~s}$, a step potential of $1.05 \mathrm{mV}$, a modulation amplitude of 
$250 \mathrm{mV}, \mathrm{E}_{\mathrm{ads}}=0 \mathrm{~V}$. Temperature of supporting electrolyte was $4{ }^{\circ} \mathrm{C}$ (Julabo, Germany). For other details see $[31,32,40,41]$.

\section{$2.3 \mathrm{pH}$ measurement}

The $\mathrm{pH}$ was measured using $\mathrm{pH}$ meter WTW inoLab (Weilheim, Germany). The pH-electrode (SenTix- H, pH 0-14/3M KCl) was regularly calibrated by set of WTW buffers (Weilheim, Germany).

\subsection{Species examined}

Nine different species of vertebrates were used for the comparative study. These included two reptilian species (Reptilia), i.e. Red-eared Slider (Trachemys scripta elegans) and Bearded Dragon (Pogona vitticeps), one avian species (Aves), i.e. Domestic Fowl (Gallus gallus f. domestica), and six mammalian species (Mammalia). Mammals were selected so as to represent carnivores, i.e. Grey Wolf (Canis lupus lupus), and herbivores belonging to three families of artiodactylids, i.e. Bactrian Camel (Camelus bactrianus; Camelidae), Reindeer (Rangifer tarandus tarandus; Cervidae), Takin (Budorcas taxicolor; Bovidae), European Bison (Bison bonasus bonasus; Bovidae), and Red Deer (Cervus elaphus; Cervidae).

\subsection{Samples and their preparation prior metallothionein analysis}

Blood plasma samples of several zoo animals (ZOO Brno, Czech Republic) and game birds (Game Bird Farm Jinacovice, University of Veterinary and Pharmaceutical Sciences Brno, Czech Republic) were used for analyses. Blood was collected during routine health status check from vena ulnaris (birds) or vena jugularis using a hypodermic needle and a syringe in the volume not threatening the animal. Heparin (HEPARIN LÉČIVA $5000 \mathrm{iu} / 1 \mathrm{ml}$ ) was used as an anticoagulant. Immediately after collection, blood was centrifuged for $5 \mathrm{~min}$ at $3000 \mathrm{~g}$. Then, plasma was separated and frozen in $1.5 \mathrm{ml}$ Eppendorf vials prior further analysis. The sample was prepared by heat treatment. Briefly, the sample was kept at $99{ }^{\circ} \mathrm{C}$ in a thermomixer (Eppendorf 5430, USA) for $15 \mathrm{~min}$ with occasional stirring, and then cooled to $4^{\circ} \mathrm{C}$. The denatured homogenates were centrifuged at $4{ }^{\circ} \mathrm{C}, 15000 \mathrm{~g}$ for $30 \mathrm{~min}$. (Eppendorf 5402, USA). Heat treatment effectively denatures and removes high molecular weight proteins out from samples [35,42].

\subsection{Statistical analysis}

MICROSOFT EXCEL® (USA) was used for statistical analyses. Results are expressed as mean \pm S.D. unless noted otherwise. Differences with $\mathrm{p}<0.05$ were considered significant.

\section{Results}

\subsection{Shape of DP voltammetric curves of mammalian species analysed}

Prepared blood plasma samples of individual animal species were analysed by the adsorptive transfer stripping technique in $5 \mu \mathrm{l}$ drop of the sample (Figure 2). In this way, species specific voltammograms were measured. Typical DP voltammograms of samples from the animals species 
analysed are shown in Figure 3. Quite distinct records were obtained from the Takin (Budorcas taxicolor), while other interesting records were observed in samples from the European Bison (Bison bonasus bonasus) and the Red-eared Slider (Trachemys scripta elegans). Moreover the shapes of DP voltammetric curves are so called specie-characteristic. Based on the shape of the curve the animal specie can be identified (patent PV 2007-568).

The Brdicka reaction can be considered as a suitable technique to determine proteins containing the thiol group. Catalytic signals of hydrogen separation provided by proteins on the mercury electrode in the presence of ammonium buffer $\left(1 \mathrm{M} \mathrm{NH}_{4} \mathrm{Cl}+\mathrm{NH}_{4} \mathrm{OH}\right)$ with content of the cobalt salt $\mathrm{Co}\left(\mathrm{NH}_{3}\right)_{6} \mathrm{Cl}_{3}$ are used [32,43-45]. Metallothionein gives four distinct signals Co1, $\mathrm{RS}_{2} \mathrm{Co}$, Cat1, and Cat2 on the electrochemical record. Recently it has been shown that this technique may be utilized for determination of metallothionein in whole blood and blood sera of humans $[32,46]$. To quantify metallothionein we used the catalytic peak Cat2, well developed in the samples from Domestic Fowl (Gallus gallus $f$. domestica) and showing a very low signal in the Red Deer (Cervus elaphus). Metallothionein levels determined in the individual animal species are shown in Figure 4. The highest levels of metallothionein reaching over $20 \mu \mathrm{M}$ were found in the Domestic Fowl. High levels of MT were also found in the Bearded Dragon (Pogona vitticeps) and the Grey Wolf (Canis lupus lupus). The lowest values of around 1-3 $\mu \mathrm{M}$ were determined in the Red-eared Slider (Trachemys scripta elegans), Takin (Budorcas taxicolor) and Red Deer (Cervus elaphus).

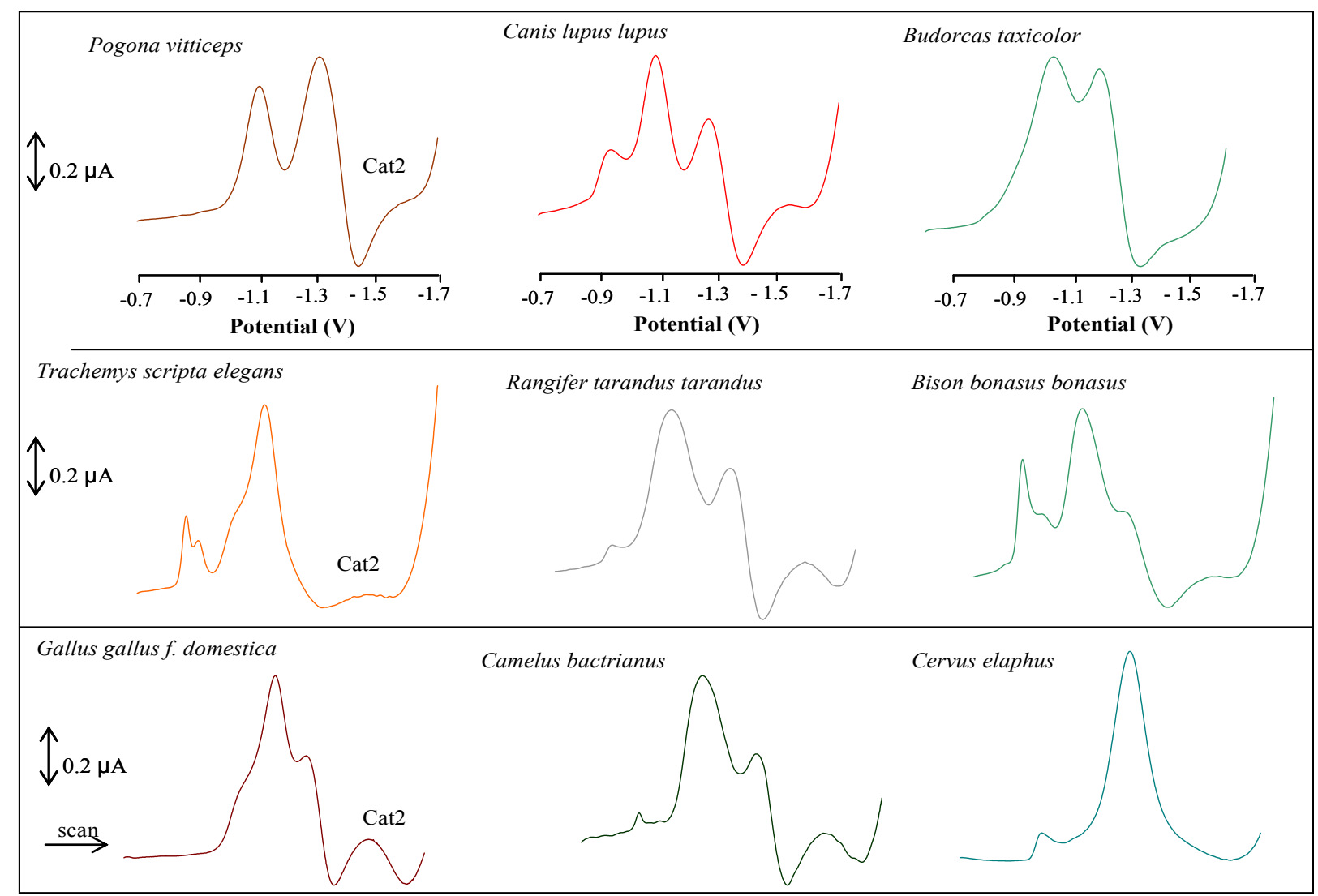

Figure 3. Characteristic voltammograms of blood plasma samples of nine animal species analysed. 
3.2 Association of changes in metallothionein level in blood of the vertebrates and their taxonomic group

As shown above, this study evaluated differences in blood levels of metallothionein in 9 animal species belonging to rather unrelated taxonomic groups. Comparison of results with references can be a problem because the only study concerning species variation in metallothionein concerns its hepatic levels and a different list of 15 species examined [26]. It is clear that the highest blood MT levels are in birds, insectivorous lizards and carnivores. Lower MT levels are in herbivorous animals, of which the Red Deer and Takin show the lowest MT findings. Henry et al. found the lowest MT levels in all examined rodents [26]. This taxonomic group, however, was not the subject of the present study. Marked species differences may be hypothetically explained by different roles of metallothioneins in the organism such as homeostasis of essential metals including zinc and copper, protection against metal toxicity and oxidative damage [47]. In this respect, organisms of higher trophic levels (birds, lizards, carnivores) may be supposed to be more subjected to the action of environmental and nutritional stressors, needing thus higher levels of MTs for the maintenance of body homeostasis. On the other hand, the results may be expected to really express species differences in blood metallothioneins because samples collected from non-stressed animals only were included to the study. Considering heavy metals, the main way of entrance into the organism is that by ingestion. Plants, as the essential food source of herbivores, may become contaminated from the atmosphere and soils. Lichens and mosses, for example, belong to susceptible bio-indicators of environmental pollution by heavy metals [48-51]. Moreover, the Reindeer are trophic specialists preferring this feed [52,53].

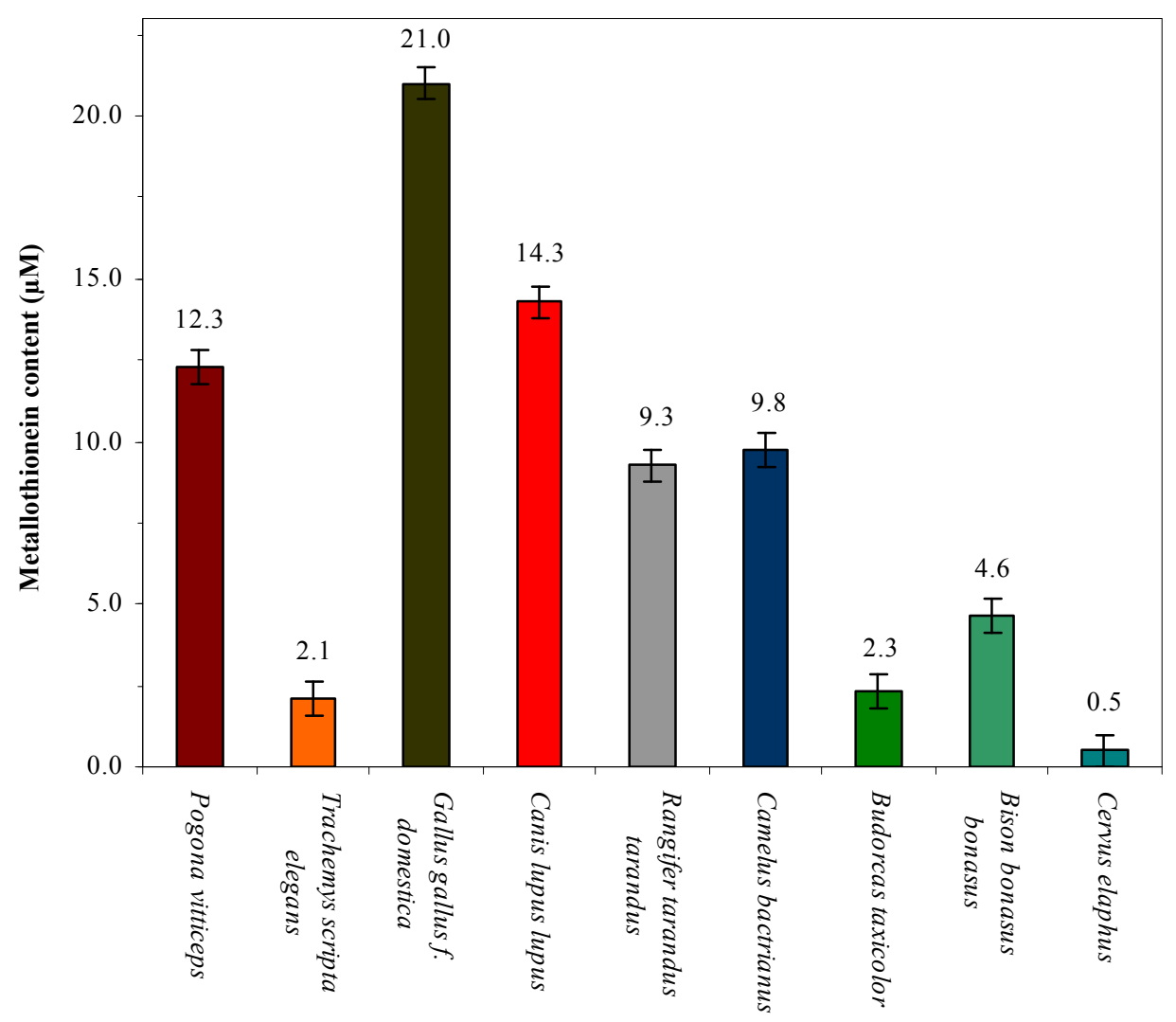

Animal species
Figure 4. Metallothionein levels in individual animal species evaluated using a calibration curve. 
Free-ranging European Bisons have been found to accumulate more cadmium in the liver and kidneys than domestic cattle [54] and, actually, this species was found with twice higher levels of metallothionein than the Takin belonging to the same family of Bovidae. Apart from lichens and mosses, direct bio-indication of heavy metals is possible using some mushrooms, herbs, trees and shrubs [55]. The above listed items are commonly included in the forage of herbivores. Contrary to terrestrial ecosystems, there are many studies on heavy metals in different aquatic trophic levels. Much attention has been paid to heavy metals in fish; with the highest levels determined in predatory species [56-59]. Interestingly, the only aquatic species evaluated in this study, i.e. the Red-eared Slider, showed low levels of metallothionein.

\section{Conclusion}

Blood levels of metallothionein have not yet been reported from any animal species except humans. This study reports on study of variation in blood level of metallothionein in different species of vertebrates. It can be concluded that metallothionein levels depend on the trophic level of the organism.

\section{Acknowledgements}

We gratefully acknowledge the following grant agency for financial support to this work: MSMT 6215712402 from The Czech Ministry of Education. The authors wish to express their thanks to Pavlina Sobrova for excellent technical assistance.

\section{References}

1. Bremner, I.; Beattie, J.H. Metallothionein and the Trace Minerals. Annu. Rev. Nutr. 1990, 10, 6383.

2. Brady, F.O. The Physiological-Function of Metallothionein. Trends Biochem. Sci. 1982, 7, 143145.

3. Meneghini, R. Iron homeostasis, oxidative stress, and DNA damage. Free Radic. Biol. Med. 1997, 23, 783-792.

4. Margoshes, M.; Vallee, B.L.A. A cadmium protein from equine kidney cortex. J. Am. Chem. Soc. 1957, 79, 4813-4814.

5. Kagi, J.H.R.; Schaffer, A. Biochemistry of Metallothionein. Biochemistry 1988, 27, 8509-8515.

6. Hamer, D.H. Metallothionein. Annu. Rev. Biochem. 1986, 55, 913-951.

7. Dunn, M.A.; Blalock, T.L.; Cousins, R.J. Metallothionein. Proc. Soc. Exp. Biol. Med. 1987, 185, 107-119.

8. Kizek, R.; Trnkova, L.; Palecek, E. Determination of metallothionein at the femtomole level by constant current stripping chronopotentiometry. Anal. Chem. 2001, 73, 4801-4807.

9. Prusa, R.; Svoboda, M.; Blastik, O.; Adam, V.; Zitka, O.; Beklova, M.; Eckschlager, T.; Kizek, R. Increase in content of metallothionein as marker of resistence to cisplatin treatment. Clin. Chem. 2006, 52, A174-A175.

10. Strouhal, M.; Kizek, R.; Vecek, J.; Trnkova, L.; Nemec, M. Electrochemical study of heavy metals and metallothionein in yeast Yarrowia lipolytica. Bioelectrochemistry 2003, 60, 29-36. 
11. Trnkova, L.; Kizek, R.; Vacek, J. Catalytic signal of rabbit liver metallothionein on a mercury electrode: a combination of derivative chronopotentiometry with adsorptive transfer stripping. Bioelectrochemistry 2002, 56, 57-61.

12. Miura, N.; Koizumi, S. Heavy metal responses of the human metallothionein isoform genes. Yakugaku Zasshi-J. Pharm. Soc. Jpn. 2007, 127, 665-673.

13. Otsuka, F.; Ohno, S.; Suzuki, K.; Takahashi, K.; Ohsawa, M.; Koizumi, S. Mechanism of metallothionein gene activation mediated by heavy-metal dependent transcription factor MTF-1. Yakugaku Zasshi-J. Pharm. Soc. Jpn. 2007, 127, 675-684.

14. Itoh, N.; Kimura, T. Cytokine-induced metallothionein expression and modulation of cytokine expression by metallothionein. Yakugaku Zasshi-J. Pharm. Soc. Jpn. 2007, 127, 685-694.

15. Min, K.S. The physiological significance of metallothionein in oxidative stress. Yakugaku ZasshiJ. Pharm. Soc. Jpn. 2007, 127, 695-702.

16. Sato, M.; Suzuki, S. Endoplasmic reticulum stress and metallothionein. Yakugaku Zasshi-J. Pharm. Soc. Jpn. 2007, 127, 703-708.

17. Satoh, M. Analysis of toxicity using metallothionein knockout mice. Yakugaku Zasshi-J. Pharm. Soc. Jpn. 2007, 127, 709-717.

18. Piskorova, L.; Vasilkova, Z.; Krupicer, I. Heavy metal residues in tissues of wild boar (Sus scrofa) and red fox (Vulpes vulpes) in the Central Zemplin region of the Slovak Republic. Czech J. Anim. Sci. 2003, 48, 134-138.

19. Hejtmankova, A.; Kucerova, J.; Miholova, D.; Kolihova, D.; Orsak, M. Levels of selected macroand microelements in goat milk from farms in the Czech Republic. Czech J. Anim. Sci. 2002, 47, 253-260.

20. Spurny, P.; Mares, J.; Hedbavny, J.; Sukop, I. Heavy metal distribution in the ecosystems of the upper course of the Jihlava River. Czech J. Anim. Sci. 2002, 47, 160-167.

21. Rous, P.; Jelinek, P. The effect of increased soil contamination with heavy metals on their content in some rabbit tissues. Czech J. Anim. Sci. 2000, 45, 319-324.

22. Thirumoorthy, N.; Kumar, K.T.M.; Sundar, A.S.; Panayappan, L.; Chatterjee, M. Metallothionein: An overview. World J. Gastroenterol. 2007, 13, 993-996.

23. Amiard, J.C.; Amiard-Triquet, C.; Barka, S.; Pellerin, J.; Rainbow, P.S. Metallothioneins in aquatic invertebrates: Their role in metal detoxification and their use as biomarkers. Aquat. Toxicol. 2006, 76, 160-202.

24. Coyle, P.; Philcox, J.C.; Carey, L.C.; Rofe, A.M. Metallothionein: The multipurpose protein. Cell. Mol. Life Sci. 2002, 59, 627-647.

25. Vasak, M.; Hasler, D.W. Metallothioneins: new functional and structural insights. Curr. Opin. Chem. Biol. 2000, 4, 177-183.

26. Henry, R.B.; Liu, J.; Choudhuri, S.; Klaassen, C.D. Species Variation in Hepatic Metallothionein. Toxicol. Lett. 1994, 74, 23-33.

27. Adam, V.; Petrlova, J.; Potesil, D.; Zehnalek, J.; Sures, B.; Trnkova, L.; Jelen, F.; Kizek, R. Study of metallothionein modified electrode surface behavior in the presence of heavy metal ionsbiosensor. Electroanalysis 2005, 17, 1649-1657.

28. Vacek, J.; Petrek, J.; Kizek, R.; Havel, L.; Klejdus, B.; Trnkova, L.; Jelen, F. Electrochemical determination of lead and glutathione in a plant cell culture. Bioelectrochemistry 2004, 63, 347351. 
29. Kizek, R.; Vacek, J.; Trnkova, L.; Jelen, F. Cyclic voltammetric study of the redox system of glutathione using the disulfide bond reductant tris(2-carboxyethyl)phosphine. Bioelectrochemistry 2004, 63, 19-24.

30. Hubalek, J.; Hradecky, J.; Adam, V.; Krystofova, O.; Huska, D.; Masarik, M.; Trnkova, L.; Horna, A.; Klosova, K.; Adamek, M.; Zehnalek, J.; Kizek, R. Spectrometric and voltammetric analysis of urease - nickel nanoelectrode as an electrochemical sensor. Sensors 2007, 7, 12381255 .

31. Adam, V.; Zehnalek, J.; Petrlova, J.; Potesil, D.; Sures, B.; Trnkova, L.; Jelen, F.; Vitecek, J.; Kizek, R. Phytochelatin modified electrode surface as a sensitive heavy-metal ion biosensor. Sensors 2005, 5, 70-84.

32. Petrlova, J.; Potesil, D.; Mikelova, R.; Blastik, O.; Adam, V.; Trnkova, L.; Jelen, F.; Prusa, R.; Kukacka, J.; Kizek, R. Attomole voltammetric determination of metallothionein. Electrochim. Acta 2006, 51, 5112-5119.

33. Adam, V.; Hanustiak, P.; Krizkova, S.; Beklova, M.; Zehnalek, J.; Trnkova, L.; Horna, A.; Sures, B.; Kizek, R. Palladium biosensor. Electroanalysis 2007, 19, 1909-1914.

34. Adam, V.; Krizkova, S.; Zitka, O.; Trnkova, L.; Petrlova, J.; Beklova, M.; Kizek, R. Determination of apo-metallothionein using adsorptive transfer stripping technique in connection with differential pulse voltammetry. Electroanalysis 2007, 19, 339-347.

35. Huska, D.; Zitka, O.; Adam, V.; Beklova, M.; Krizkova, S.; Zeman, L.; Horna, A.; Havel, L.; Zehnalek, J.; Kizek, R. A sensor for investigating the interaction between biologically important heavy metals and glutathione. Czech J. Anim. Sci. 2007, 52, 37-43.

36. Krizkova, S.; Adam, V.; Petrlova, J.; Zitka, O.; Stejskal, K.; Zehnalek, J.; Sures, B.; Trnkova, L.; Beklova, M.; Kizek, R. A suggestion of electrochemical biosensor for study of platinum(II)-DNA interactions. Electroanalysis 2007, 19, 331-338.

37. Petrlova, J.; Potesil, D.; Zehnalek, J.; Sures, B.; Adam, V.; Trnkova, L.; Kizek, R. Cisplatin electrochemical biosensor. Electrochim. Acta 2006, 51, 5169-5173.

38. Trnkova, L.; Jelen, F.; Petrlova, J.; Adam, V.; Potesil, D.; Kizek, R. Elimination voltammetry with linear scan as a new detection method for DNA sensors. Sensors 2005, 5, 448-464.

39. Palecek, E.; Postbieglova, I. Adsorptive Stripping Voltammetry of Biomacromolecules with Transfer of the Adsorbed Layer. J. Electroanal. Chem. 1986, 214, 359-371.

40. Supalkova, V.; Huska, D.; Diopan, V.; Hanustiak, P.; Zitka, O.; Stejskal, K.; Baloun, J.; Pikula, J.; Havel, L.; Zehnalek, J.; Adam, V.; Trnkova, L.; Beklova, M.; Kizek, R. Electroanalysis of plant thiols. Sensors 2007, 7, 932-959.

41. Supalkova, V.; Petrek, J.; Baloun, J.; Adam, V.; Bartusek, K.; Trnkova, L.; Beklova, M.; Diopan, V.; Havel, L.; Kizek, R. Multi-instrumental investigation of affecting of early somatic embryos of spruce by cadmium(II) and lead(II) ions. Sensors 2007, 7, 743-759.

42. Krizkova, S.; Zitka, O.; Adam, V.; Beklova, M.; Horna, A.; Svobodova, Z.; Sures, B.; Trnkova, L.; Zeman, L.; Kizek, R. Possibilities of electrochemical techniques in metallothionein and lead detection in fish tissues. Czech J. Anim. Sci. 2007, 52, 143-148.

43. Brdicka, R. Polarographic studies with the dropping mercury kathode. -Part XXXI. - A new test for proteins in the presence of cobalt salts in ammoniacal solutions of ammonium chloride. Coll. Czech. Chem. Commun. 1933, 5, 112-128.

44. Brdicka, R. Polarographic Studies with the Dropping Mercury Kathode. -Part LXI. - The Effect of buffer Solutions on the Reaction of Proteins. Coll. Czech. Chem. Commun. 1936, 8, 366-376. 
45. Erk, M.; Ivanković, D.; Raspor, B.; Pavičić, J. Evaluation of different purification procedures for the electrochemical quantification of mussel metallothioneins. Talanta 2002, 57, 1211-1218.

46. Kukacka, J.; Vajtr, D.; Huska, D.; Prusa, R.; Houstava, L.; Samal, F.; Diopan, V.; Kotaska, K.; Kizek, R. Blood metallothionein, neuron specific enolase, and protein S100B in patients with traumatic brain injury. Neuroendocrinol. Lett. 2006, 27, 116-120.

47. Palmiter, R.D. The elusive function of metallothioneins. Proc. Natl. Acad. Sci. U. S. A. 1998, 95, 8428-8430.

48. Garty, J. The Amounts of Heavy-Metals in Some Lichens of the Negev Desert. Environ. Pollut. Ser. B-Chem. Phys. 1985, 10, 287-300.

49. Garty, J.; Ammann, K. The Amounts of Ni, Cr, Zn, Pb, Cu, Fe and $\mathrm{Mn}$ in Some Lichens Growing in Switzerland. Environ. Exp. Bot. 1987, 27, 127-138.

50. Ikingura, J.R.; Akagi, H. Lichens as a good bioindicator of air pollution by mercury in small-scale gold mining areas, Tanzania. Bull. Environ. Contam. Toxicol. 2002, 68, 699-704.

51. Pawlik-Skowronska, B.; di Toppi, L.S.; Favali, M.A.; Fossati, F.; Pirszel, J.; Skowronski, T. Lichens respond to heavy metals by phytochelatin synthesis. New Phytol. 2002, 156, 95-102.

52. Munshower, F.F.; Neuman, D.R. Metals in Soft-Tissues of Mule Deer and Antelope. Bull. Environ. Contam. Toxicol. 1979, 22, 827-832.

53. Froslie, A.; Norheim, G.; Rambaek, J.P.; Steinnes, E. Levels of Trace-Elements in Liver from Norwegian Moose, Reindeer and Red Deer in Relation to Atmospheric Deposition. Acta Vet. Scand. 1984, 25, 333-345.

54. Wlostowski, T.; Bonda, E.; Krasowska, A. Free-ranging European bisons accumulate more cadmium in the liver and kidneys than domestic cattle in north-eastern Poland. Sci. Total Environ. 2006, 364, 295-300.

55. Cibulka, J.; Domazlicka, E.; Kozak, J.; Kubiznakova, J.; Mader, P.; Machalek, E.; Mankovska, B.; Musil, J.; Parizek, J.; Pisasa, J.; Pohunkova, H.; Reisnerova, H.; Svobodova, Z. Movement of lead, cadmium and mercury in the biosphere; Acedemia: Prague, 1991; pp 432.

56. Svobodova, Z.; Celechovska, O.; Kolarova, J.; Randak, T.; Zlabek, V. Assessment of metal contamination in the upper reaches of the Ticha Orlice River. Czech J. Anim. Sci. 2004, 49, 458464.

57. Svobodova, Z.; Zlabek, V.; Celechovska, O.; Randak, T.; Machova, J.; Kolarova, J.; Janouskova, D. Content of metals in tissues of marketable common carp and in bottom sediments of selected ponds of South and West Bohemia. Czech J. Anim. Sci. 2002, 47, 339-350.

58. Celechovska, O.; Svobodova, Z.; Randak, T. Arsenic content in tissues of fish from the River Elbe. Acta Vet. BRNO 2005, 74, 419-425.

59. Zlabek, V.; Svobodova, Z.; Randak, T.; Valentova, O. Mercury content in the muscle of fish from the Elbe River and its tributaries. Czech J. Anim. Sci. 2005, 50, 528-534.

C 2007 by MDPI (http://www.mdpi.org). Reproduction is permitted for noncommercial purposes. 